\title{
Gender Differences in Work Modifications and Changed Job Characteristics During the Return-To-Work Process: A Prospective Cohort Study
}

\author{
A. De Rijk $\cdot$ F. Nijhuis $\cdot$ K. Alexanderson
}

Published online: 27 February 2009

(c) The Author(s) 2009. This article is published with open access at Springerlink.com

\begin{abstract}
Objectives To describe gender differences in work modifications and changed job characteristics during return-to-work after sickness absence. Methods A 13 month prospective cohort study was performed among 119 employees (54 women and 65 men) who had reported sick for more than 1 month due to mental or musculoskeletal disorders. Men and women were of comparable ages and educational levels, worked in similar sectors, at corresponding functional levels, and were experiencing the same types of health disorders. They were interviewed bi-monthly. Work modifications and job characteristics were assessed at return-to-work. Job characteristics were also assessed upon the employee's inclusion in the study. Results Work modifications occurred in $77.4 \%$ of the return-to-work attempts (no gender differences); reduced working hours, reduced work pace, or task reassignments were most frequent. Compared to men, reduced hours and pace were more often used for women between 12 and 20 weeks of absence $(P>0.001$ and $0.01<P<0.001$ respectively) and reduced hours also during the whole period $(0.01<P<0.001)$. Applying reduced hours related to type of disorder in men and applying different time-schedules in women. Upon return to work both women and men reported increased job autonomy and emotional demands $(P<0.001)$; women reported more job satisfaction $(P<0.001)$. Conclusions
\end{abstract}

\footnotetext{
A. De Rijk $(\bowtie) \cdot$ F. Nijhuis

Faculty of Health, Medicine and Life Sciences, Department of Social Medicine, Maastricht University, P.O. Box 616, 6200, MD, Maastricht, The Netherlands

e-mail: Angelique.derijk@socmed.unimaas.nl;

a.derijk@beoz.unimaas.nl

A. De Rijk · K. Alexanderson

Section for Personal Injury Prevention, Karolinska Institutet, Stockholm, Sweden
}

Work modifications were widely applied during the returnto-work process and predominantly aimed at reduction of pressure at work. Women had a few more work modifications. The marginal gender differences may be due to male and female respondents having similar characteristics. Upon return to work some job characteristics improved.

Keywords Return-to-work - Work modifications · Job characteristics - Gender - Sickness absence

\section{Introduction}

Return to work after sickness absence is receiving increasing attention in the international literature. Authors refer to the societal costs of absence [e.g., 1, 2] and to the improvement in the quality of life of those who return to work [e.g., 1, 3]. Yet, the return-to-work process itself is rarely studied. In a systematic review of the effectiveness of workplace-based return-to-work interventions, Franche et al. [4] found only ten studies of sufficient quality. However, the fact that sickness absence duration was significantly reduced by work modifications was an important finding. Moreover, unchanged psychosocial job characteristics constitute an important barrier to returning to work [5]. Recommendations regarding proactive return-to-work policies focusing on reduced physical and psychosocial exposures are published [6], however, little is known regarding the extent to which these recommendations are actually used in daily practice.

Furthermore, the (scarce) literature suggests that fewer measures are taken for female employees when returning to work after sickness absence than for male employees [7, 8]. Moreover, there are indications that women who reported sick due to work-related strain more often report that their 
work situations has not change resulting in increased stress during re-integration and relapse, thus prolonging sickness absence [9, 10]. Cuelenaere [7] has shown that employers put less effort and creativity towards improving working conditions for female employees suffering from back pain as compared to male employees. These employees under study had the same jobs (cleaning jobs). There are thus good reasons to interpret the lack of job modifications for women on sick leave as a sign of gender-based job discrimination. This lack may be one explanation for the higher rates of sickness absence and lower rates of return-to-work after sickness absence among women in northern European countries [2, 11-16]. In other words, if sick-listed men and women would be offered the same degree of job modifications, this would probably reduce the gender difference in sickness absence somewhat. In an earlier study regarding Dutch employees sick-listed for more than 1 month, we reported that women needed more time for lasting return to work (that is, re-integration without relapse into sickness absence) than men [17]. One of the reasons for these findings may be the lack of measures taken for women.

Consequently, this study aims to describe possible gender differences in work-related measures taken during the return-to-work process in male and female employees that are comparable regarding social-demographic and work characteristics.

The study further focused on employees who reported sick for longer lasting disorders that belonged to two of the most important categories of complaints among those on disability pension in The Netherlands [18]: (1) mental complaints, such as overstrain and burnout, or (2) musculoskeletal complaints such as lower back pain, repetitive strain injuries, whiplash etc. Dutch law recommends that employers allow sick-listed employees an initial partial return to work during sickness absence. This is a work modification that may promote health and result in successful re-integration. Other modifications include: schedule changes, modifying or reassignment of tasks, changing the function or job, reducing the pace of work, transferring to another department and modification of the workstation (furniture; equipment) [19]. In a Dutch study of patients with rheumatoid arthritis who continued to work, Verstappen et al. [20] found that reduced working hours (46\%), reduced pace of work (42\%), or help from colleagues (49\%) were the most important modifications that promoted continued presence at work.

Krause et al. [5], found that unchanged job characteristics led to longer disability. Job characteristics refer to the regularly studied features of work such as demands, autonomy, and social support from supervisors and colleagues. Conversely, Johansson et al. [21] found that improving adjustment latitude, one aspect of work autonomy, increased the likelihood of return to work among both men and women. Employees and employers may thus regard sickness absence as an indication that changes are required in the workplace and it may be expected that generally job characteristics will improve after sickness absence. However, it may be that changes are made less often for women [8-10]. The aim of this study is to describe gender differences in the return-to-work process in the:

- Application of work modifications

- Changes in job characteristics

\section{Method}

We conducted a prospective cohort study of 119 employees who reported sick for more than 1 month. Data were collected from the employees at seven different occasions during the 13 months following the first time the employee reported sick.

\section{Sample}

The sample consisted of 119 employees who, because of their sickness absence, had accessed one of 17 Occupational Health Services (OHS) organizations throughout The Netherlands between the 1st of May and the 1st of November, 2000. Participants were recruited by 48 occupational physicians (response 56.5\%) and asked to participate in a longitudinal cohort study. The employee inclusion criteria (judged by the occupational physician) were: having reported sick for at least 1 month; the employee was between 16 and 61 years of age; the employee had an contract for $20 \mathrm{~h}$ per week or more; the absenteeism related to mental or musculoskeletal disorders; the employee had worked in sector or a department with a gender-mixed composition (at least 25\% males/females). (On the basis of national figures about horizontal gender segregation we decided to include employees working in department stores, supermarkets, hotels/restaurants/pubs, cleaning companies, industry, financial and private services, governmental bodies, or non-profit sectors.) These criterions were formulated in order to increase comparability of male and female employees. Moreover, they also contributed to collecting comparable numbers of male and female employees in our study; and the employee agreed to their occupational physician sending in information about them to the project.

\section{Procedure and Design}

When a Dutch employee reports sick, he or she visits the occupational physician at an OHS within the first few weeks. At the time of the study, the employer had to pay 
the employee's sickness benefits and the counselling offered by the OHS for 1 year (later extended to 2 years). As a result, the occupational physicians were regarded as a good resource for accessing potential candidates. Seventeen OHSs around the country were invited to participate in the project and all agreed. At these OHSs, 48 occupational physicians agreed to participate in the study. For each OHS, the exact procedure for data collection was tailored to the specific locale.

During consultation, occupational physicians asked employees who fulfilled the inclusion criteria whether they agreed with being contacted by the Maastricht University for the project. If they agreed, the employees received a study brochure and the occupational physician filled out a simple form (T1) which was sent to the university. If the employee was still interested when contacted, he or she received an informed consent form by post. Moreover, an appointment was made for a structured face-to-face interview (T2) at the employee's home lasting about one hour. These interviews took place at $12.1(\mathrm{SD}=3.9)$ weeks after reporting sick (range 3.3-22.0 weeks).

Further, employees were interviewed every other month by telephone during the year following reporting sick (T3-T7). Employees were not re-interviewed if they had reported having fully returned to work during two consecutive follow-up calls. All employees were interviewed at T2, T3, and T7. There were no gender differences in the timing of each call. On average, the study period lasted 53.7 weeks following the first day the employee reported sick (no gender differences).

\section{Response}

Initially, 94 occupational physicians agreed to participate in the study but only 48 (56.6\%) sent in information about employees who fulfilled all the inclusion criteria. 126 employees met the inclusion criteria and agreed to participate, also stated in an informed consent. Seven dropped out after the first interview (response rate 94.4\%). At the start, men with psychological diagnoses seemed to refuse participation more often because of hesitations about the study's content. To ensure participation of this group, we first asked participation for the face-to-face interview and explained the full intent and participant contribution to the whole study after that interview.

Data analysis was performed using the information gathered from 119 employees, 65 men and 54 women. Sample characteristics are presented in Table 1. Gender differences reflect the characteristic nature of the Dutch workforce: female employees tend to work more part-time and are more highly educated than male employees [22]. Table 1 displays the sample characteristics of the 119 employees that participated.
The sample was a comparable mix of women and men. The employees were of comparable age, educational level, employment sector, functional level, and had similar health complaints. Half of the sample suffered from mental disorders, mainly overstrain or burnout, some depression or anxiety disorders. The rest had musculoskeletal disorders, predominantly back pain or repetitive strain injury disorders.

\section{Data Obtained}

Structured questionnaires for the face-to-face and telephone interviews were constructed.

\section{Return-To-Work (T2-T7)}

Return-to-work referred to all types of working again, disregarding one's income type. It could be full (for the hours as stated in the employment contract) or partial (less than the hours in the contract). It was possible to return to work while still being sick-listed and receiving sickness absence benefit; this is called 'therapeutic' reintegration' and was scored as return-to-work. If one choosed not to work when not reported sick (e.g., when making use of early retirement arrangements) this was scored as not returning to work.

\section{Work Modifications (T2-T7)}

If an employee had returned to work they were asked: Has the job been adapted since the last interview or, during the first interview: since the first day of sickness absence? If this question was answered with 'yes', the interviewer asked: Which of the following strategies were used to adapt the job: reduced hours; different schedules; modified or reduced tasks; changing function or job; reduced pace of work; transferring to another department; or modification of the workstation (e.g., furniture, equipment). Each item was asked and scored if had happened by the interviewer [19]. Initiatives for work modifications could be taken by employer, occupational physician or employee; this was not asked.

\section{Job Characteristics (T2-T7)}

During the first interview, information about the employee's job characteristics before reporting sick was collected. If during an interview the employee appeared to have returned to work for the full amount of hours, the newly experienced job characteristics were collected. All items were measured with a dichotomous answering scale (no $=1$; yes $=2$ ) and covered the following aspects: 
Table 1 Participant characteristics
* $0.05>P>0.01$

** $0.01>P>0.001$

*** $P<0.001$

\begin{tabular}{|c|c|c|c|}
\hline & $\begin{array}{l}\text { Man } \\
(n=65)\end{array}$ & $\begin{array}{l}\text { Women } \\
(n=54)\end{array}$ & $\begin{array}{l}\text { Total } \\
(n=119)\end{array}$ \\
\hline \multicolumn{4}{|l|}{ Age } \\
\hline $16-35$ & $14(21.6 \%)$ & $19(35.2 \%)$ & $33(27.7 \%)$ \\
\hline $36-45$ & $19(29.2 \%)$ & $16(29.6 \%)$ & $35(29.4 \%)$ \\
\hline $46-60$ & $32(49.2 \%)$ & $19(35.2 \%)$ & $51(42.9 \%)$ \\
\hline \multicolumn{4}{|l|}{ Educational level } \\
\hline Primary school/secondary school lower level & $26(40.0 \%)$ & $22(40.8 \%)$ & $48(40.3 \%)$ \\
\hline High school/college/polytechnic/university & $39(60.0 \%)$ & $32(59.3 \%)$ & $71(59.6 \%)$ \\
\hline Working hours per week $* * *$ & $36.77(5.15)$ & $30.12(7.57)$ & $33.63(7.20)$ \\
\hline \multicolumn{4}{|l|}{ Sector } \\
\hline $\begin{array}{l}\text { Department store, supermarket, hotel and catering } \\
\text { industry, cleaning industry }\end{array}$ & $5(7.9 \%)$ & $5(9.6 \%)$ & $10(8.7 \%)$ \\
\hline Industrial manufacture & $13(20.6 \%)$ & $6(11.5 \%)$ & $19(16.5 \%)$ \\
\hline Financial and commercial services & $19(30.2 \%)$ & $16(30.8 \%)$ & $35(30.4 \%)$ \\
\hline $\begin{array}{l}\text { Public service (government, education, health care) } \\
\text { and non-profit organizations }\end{array}$ & $26(41.3 \%)$ & $25(48.1 \%)$ & $51(44.3 \%)$ \\
\hline \multicolumn{4}{|l|}{ Functional level } \\
\hline Blue collar/white collar routine level & $41(63.1 \%)$ & $37(68.5 \%)$ & $78(65.5 \%)$ \\
\hline Medium and higher level white collar & $22(33.9 \%)$ & $15(27.8 \%)$ & $37(31.1 \%)$ \\
\hline \multicolumn{4}{|l|}{ Living...* } \\
\hline With others (partner, children, and/or parents) & $56(92.3 \%)$ & $41(67.4 \%)$ & $81(38.1 \%)$ \\
\hline Alone & $4(6.7 \%)$ & $12(22.6 \%)$ & $16(13.4 \%)$ \\
\hline \multicolumn{4}{|l|}{ Complaint/disorder } \\
\hline Mental & $28(43.1 \%)$ & $29(53.7 \%)$ & $57(47.9 \%)$ \\
\hline Musculoskeletal & $37(56.9 \%)$ & $25(46.3 \%)$ & $62(52.1 \%)$ \\
\hline Born in The Netherlands & $61(93.8 \%)$ & $51(94.4 \%)$ & $112(94.1 \%)$ \\
\hline
\end{tabular}

- Job autonomy. This was measured with the 6-item scale from the Maastricht Autonomy Questionnaire (MAQ) [23]; $\alpha=0.77$. Example: Do you have the opportunity to pause in our work whenever you want?

- Emotional demands. This was measured with four items from the Dutch VAG [24], the Dutch VBBA [25], and one item was self-formulated; $\alpha=0.63$. Example: In your work, are you confronted with things that affect you personally?

- Opportunities for learning and career development. This was measured by three items from the Dutch VBBA [25] and the DLO [26]; $\alpha=0.63$. Example: Does your company offer enough opportunities to attend additional education or courses?

- Commitment. This was measured by three items from the Dutch VBBA [25]; $\alpha=0.58$. Example: Do your opinions agree with those of your company?

The following scales were measured with a four category response scale $(1=$ entirely disagree to $4=$ entirely agree).

- Psychological work demands. This was measured with a five item scale from the Job Content Questionnaire [27] using a Dutch translation of Houtman [28]. The scale was computed by multiplying the first items by three and the others with two; $\alpha=0.75$. Example: My job requires working very hard.

- Support from colleagues. This was measured by four items from the Job Content Questionnaire [27] in a Dutch translation of Houtman [28]; $\alpha=0.66$. Example: People I work with are competent in doing their jobs.

- Support from supervisor. This was measured by four items from the Job Content Questionnaire [27] in a Dutch translation of Houtman [28]; $\alpha=0.84$. Example: My supervisor pays attention to what you are saying.

Finally, job satisfaction was measured with one item that asked the respondent to evaluate the satisfaction with their work on a continuum between 0 and 100 .

\section{Analyses}

For every scheduled follow-up call, the number of each work modification measure for men and women who had returned to work was computed. Gender differences were computed with $\mathrm{Chi}^{2}$-tests.

To test changes in job characteristics between T2 and moment of return to work, multiple $t$-tests were performed. 
We only computed these within the groups of men and women who had fully returned to work at $\mathrm{T} 7$ to obtain a reasonable comparison.

\section{Results}

\section{Return-To-Work}

At T2, 52.1\% had returned to work, 55.4\% $(n=38)$ of the men and $48.1 \%(n=26)$ of the women. During the measurement period, $96.6 \%(n=115)$ tried to return to work, $78.5 \%(n=51)$ of the men and $70.4 \%(n=38)$ of the women. At T7, almost $80 \%(79.8 \%, n=95)$ of the absentees had fully or partially returned to work. Among the men, $86.2 \%$ returned $(n=66)$ and among the women $72.2 \%(n=39)$. None of the gender differences mentioned here were statistically significant.

\section{Work Modifications}

The frequencies of the work modification measures are presented in Table 2. Modifications were made in threefourths of the return-to-work cases $(77.4 \%)$, with reduced hours and reduced pace as the most frequently reported measures. In about half of the cases, employees performed different tasks after return. In about one-third of the returnto-work cases, employees worked at a different schedule, in another job/function, in another department, and/or modifications had been made to their workstation. About a quarter also reported other types of work modifications.

In general, women did not receive more work modifications than men. However, the work modification of reduced hours was more often applied to women $(89.5 \%)$ than to men $(60.8 \%)(0.001<P<0.01)$ and this difference was particularly large if employees returned early, that is before T2 (about 3 months after reporting sick). Moreover, women who returned before T2, were more likely than men to have their work pace reduced than men. When return to work occurred at a later stage, no gender differences in work modifications could be demonstrated but this is also related to the small sample sizes as almost anyone did an attempt to return. Table 2 further shows, that those who returned at the end of their year of sickness absence, all had reduced hours, a new job at another department and adaptations to their work station. The percentage of employees that were offered a new job or function and work at another department tended to increase when return to work took place later.

We also computed whether work modifications in general and specific work modifications in particular had been applied before T2 more often in relation to mental or musculoskeletal disorders $(n=62)$. In general, both within the male and female subgroups, the percentage of work modifications was equal for both disorders. For the men, reduced hours was more often applied in cases of mental disorders $(85.7 \%)$ than in cases of musculoskeletal disorders $(30.0 \%)(P<0.05)$. For the women, the measure different schedules was less often applied in cases of mental disorders $(18.2 \%)$ than in cases of musculoskeletal disorders $(80.0 \%)(0.01<P<0.001)$. Other differences in relation to disorders could not be demonstrated.

\section{Changes in Experienced Job Characteristics}

For the men and women who had returned to work at the full number of hours only, the means of the experienced job characteristics at $\mathrm{T} 2$ and at the time of return-to-work were compared. These data refer to the majority of the men and women who returned to work during the study period, although more to the men $(72.5 \%$ of the men and $55.3 \%$ of the women; $0.001<P<0.01)$ for the full amount of hours. Because full return refers here to the situation at moment of interviewing, and not to the whole period until the interview, the numbers of men and women included in these analyses differ slightly from that which can be derived from Table 2. These means are presented in Table 3. Both these men and women experienced an increase in job autonomy $(P<0.001)$ and in emotional demands $(P<0.001)$. Only the women stated increased job satisfaction $(P<0.001)$; however, their satisfaction with work at $\mathrm{T} 1$ was significantly lower than that of the men.

\section{Discussion}

In this study of long-term sickness absent women and men we found that work modifications were widely applied during the return-to-work process. In about three quarter of the cases, work modifications were made when employees returned to work; particularly those that reduced the demands of the job and pressure on the worker such as: working reduced hours and reducing the pace of work. A significant gender difference in the application of these two work modifications was demonstrated for those who returned to work during the first 3 months after sickness absence. Contrary to our hypothesis, these modifications were used more often for women than for men. No other gender differences in work modifications were found.

Those employees, who managed to work for the full amount of hours that they worked before their sickness absence, experienced increased job autonomy and increased emotional demands. Moreover, these women experienced significantly lower job satisfaction at time of inclusion compared to men, but experienced increased job 
Table 2 Percentage of men and women who had experienced different types of work modifications at return to work at different measurement occasions (T2-T7) of all who had returned to work during the year after reporting sick

\begin{tabular}{|c|c|c|c|c|c|c|c|c|c|}
\hline & $\begin{array}{l}\text { Modifications in } \\
\text { general }\end{array}$ & $\begin{array}{l}\text { Reduced } \\
\text { hours }\end{array}$ & $\begin{array}{l}\text { Different } \\
\text { schedules }\end{array}$ & $\begin{array}{l}\text { Modified/ } \\
\text { reduced tasks }\end{array}$ & $\begin{array}{l}\text { Changing } \\
\text { function or job }\end{array}$ & $\begin{array}{l}\text { Reduced pace } \\
\text { of work }\end{array}$ & $\begin{array}{l}\text { Other } \\
\text { department }\end{array}$ & $\begin{array}{l}\text { Mod. of } \\
\text { work station }\end{array}$ & Other \\
\hline $\begin{array}{l}\text { Total period } \\
\quad(n=115)\end{array}$ & $77.4 \%(89)$ & $\begin{array}{r}73.0 \% \\
(65)\end{array}$ & $36.0 \%(32)$ & $48.3 \%(43)$ & $28.1 \%(25)$ & $58.4 \%(52)$ & $31.5 \%(28)$ & $29.2 \%(26)$ & $\begin{array}{r}23.6 \% \\
(21)\end{array}$ \\
\hline Men & $75 \%(51)$ & $\begin{array}{l}60.8 \% \\
(31)^{* *}\end{array}$ & $31.4 \%(16)$ & $51.0 \%(26)$ & $27.5 \%(14)$ & $58.8 \%(30)$ & $27.5 \%(14)$ & $27.5 \%(14)$ & $\begin{array}{l}17.6 \% \\
(9)\end{array}$ \\
\hline Women & $80.9 \%(38)$ & $\begin{array}{l}89.5 \% \\
(34)^{* *}\end{array}$ & $42.1 \%(16)$ & $44.7 \%(17)$ & $28.9 \%(11)$ & $84.2 \%(32)$ & $36.8 \%(14)$ & $31.6 \%(12)$ & $\begin{array}{r}31.6 \% \\
(12)\end{array}$ \\
\hline $\begin{array}{l}\text { Until T2 } \\
\quad(n=62)\end{array}$ & $75.4 \%(48)$ & $64.6 \%$ & $37.5 \%$ & $35.4 \%$ & $14.6 \%$ & $64.6 \%$ & $8.3 \%$ & $14.6 \%$ & $18.8 \%$ \\
\hline Men & $75.0 \%(27)$ & $44.4 \% * * *$ & $29.6 \%$ & $44.4 \%$ & $14.8 \%$ & $51.9 \% *$ & $3.7 \%$ & $18.5 \%$ & $14.8 \%$ \\
\hline Women & $80.8 \%(21)$ of 26 & $90.5 \% * * *$ & $47.6 \%$ & $23.8 \%$ & $14.3 \%$ & $81.0 \% *$ & $14.3 \%$ & $9.5 \%$ & $23.8 \%$ \\
\hline $\begin{array}{l}\mathrm{T} 2-\mathrm{T} 3 \\
\quad(n=22)\end{array}$ & $68.2 \%(15)$ & $80.0 \%$ & $33.3 \%$ & $53.3 \%$ & $26.7 \%$ & $80.0 \%$ & $20.0 \%$ & $20.0 \%$ & $13.3 \%$ \\
\hline Men & $69.2 \%$ (9 of 13$)$ & $88.9 \%$ & $33.3 \%$ & $44.4 \%$ & $33.3 \%$ & $88.9 \%$ & $22.2 \%$ & $22.2 \%$ & $11.1 \%$ \\
\hline Women & $66.7 \%(6$ of 9$)$ & $66.7 \%$ & $33.3 \%$ & $66.7 \%$ & $16.7 \%$ & $66.7 \%$ & $16.7 \%$ & $16.7 \%$ & $16.7 \%$ \\
\hline $\begin{array}{l}\mathrm{T} 3-\mathrm{T} 4 \\
\quad(n=13)\end{array}$ & $61.5 \%(8)$ & $62.5 \%$ & $25.0 \%$ & - & - & $62.5 \%$ & - & - & $50.0 \%$ \\
\hline Men & $55.6 \%(5)$ & $60.0 \%$ & $20.0 \%$ & - & - & $60.0 \%$ & - & - & $40.0 \%$ \\
\hline Women & $75.0 \%$ & $66.7 \%$ & $33.3 \%$ & - & - & $66.7 \%$ & - & - & $66.7 \%$ \\
\hline $\begin{array}{l}\mathrm{T} 4-\mathrm{T} 5 \\
\quad(n=5)\end{array}$ & $100 \%(5)$ & $80.0 \%$ & $60.0 \%$ & $80.0 \%$ & $20.0 \%$ & $80.0 \%$ & $100 \%$ & $20.0 \%$ & $20.0 \%$ \\
\hline Men & $100 \%$ & $66.7 \%$ & $50.0 \%$ & $50.0 \%$ & $50.0 \%$ & $100.0 \%$ & $100 \%$ & $50.0 \%$ & $50.0 \%$ \\
\hline Women & $100 \%$ & $100.0 \%$ & $66.7 \%$ & $100.0 \%$ & $0 \%$ & $66.7 \%$ & $100 \%$ & $0 \%$ & $0 \%$ \\
\hline $\begin{array}{l}\mathrm{T} 5-\mathrm{T} 6 \\
\quad(n=8)\end{array}$ & $100 \%(8)$ & $100 \%$ & $25.0 \%$ & $62.5 \%$ & $50.0 \%$ & $75.0 \%$ & $37.5 \%$ & $25.0 \%$ & $12.5 \%$ \\
\hline Men & $100 \%$ & $100 \%$ & $0 \%$ & $100 \%$ & $66.7 \%$ & $66.7 \%$ & $33.3 \%$ & $33.3 \%$ & $0 \%$ \\
\hline Women & $100 \%$ & $100 \%$ & $40.0 \%$ & $40.0 \%$ & $40.0 \%$ & $80.0 \%$ & $40.0 \%$ & $20.0 \%$ & $20.0 \%$ \\
\hline $\begin{array}{l}\mathrm{T} 6-\mathrm{T} 7 \\
\quad(n=5)\end{array}$ & $100 \%$ & $100 \%$ & $40.0 \%$ & $20.0 \%$ & $20.0 \%$ & $80.0 \%$ & $100 \%$ & $100 \%$ & $100 \%$ \\
\hline Men & $100 \%$ & $100 \%$ & $50.0 \%$ & $25.0 \%$ & $25.0 \%$ & $75.0 \%$ & $100 \%$ & $100 \%$ & $100 \%$ \\
\hline Women & $100 \%$ & $100 \%$ & $0 \%$ & $0 \%$ & $0 \%$ & $100.0 \%$ & $100 \%$ & $100 \%$ & $100 \%$ \\
\hline
\end{tabular}

* Gender difference $0.01<P<0.05$

** Gender difference $0.001<P<0.01$

*** Gender difference $P<0.001$

Table 3 Job characteristics (mean and standard deviation) at T2 and at full return to work among male and female employees who returned for their former amount of hours

\begin{tabular}{|c|c|c|c|c|}
\hline & \multicolumn{2}{|l|}{ Men $(n=37)$} & \multicolumn{2}{|l|}{ Women $(n=21)$} \\
\hline & $\mathrm{T} 2$ & $\mathrm{~T}^{\text {returned to work }}$ & $\mathrm{T} 2$ & $\mathrm{~T}^{\text {returned to work }}$ \\
\hline Job autonomy $(1=$ no, $2=$ yes $)$ & $1.39(0.28)^{* * *}$ & $1.73(0.49)^{* * *}$ & $1.43(0.33)^{* * *}$ & $1.80(0.54)^{* * *}$ \\
\hline Emotional demands $(1=$ no, $2=$ yes $)$ & $1.22(0.31)^{* * *}$ & $1.39(0.68)^{* * *}$ & $1.33(0.26)^{* * *}$ & $1.38(0.67)^{* * *}$ \\
\hline $\begin{array}{l}\text { Opportunities for learning and career development } \\
(1=\text { no, } 2=\text { yes })\end{array}$ & $1.64(0.40)$ & $1.61(0.40)$ & $1.59(0.38)$ & $1.54(0.47)$ \\
\hline Commitment $(1=$ no, $2=$ yes $)$ & $1.66(0.36)$ & $1.61(0.50)$ & $1.56(0.39)$ & $1.51(0.41)$ \\
\hline Psychological work demands (12-48) & $31.92(3.78)$ & $32.18(7.39)$ & $32.05(4.04)$ & $31.76(10.34)$ \\
\hline Support from colleagues $(1=$ little, $4=$ much $)$ & $2.98(0.43)$ & $2.96(0.49)$ & $2.75(0.31)$ & $2.70(0.63)$ \\
\hline Support from supervisor $(1=$ little, $4=$ much $)$ & $2.58(0.68)$ & $2.67(0.65)$ & $2.28(0.57)$ & $2.65(0.64)$ \\
\hline Job satisfaction $(0-100)$ & $76.0(18.9)$ & $78.5(14.2)$ & $60.0(20.5)^{* * *}$ & $75.5(16.3) * * *$ \\
\hline
\end{tabular}

*** Gender difference $P<0.001$ 
satisfaction after sickness absence and nearly had the same level as men at the end of the study.

The studied women had not experienced less work modification measures - rather on the contrary. Women's lower probability of experiencing return-to-work without recidivation that was found in the same sample [17] can thus not be explained by a lack of access to work modifications. However, Cuelenaere [7] demonstrated that less creativity was used when it came to developing work modifications for female absentees. In similar vein, the measures reduced hours and slower pace of work found it this study may not be the most relevant interventions for women.

Work modifications were widely applied to both men and women, but there was little variety in type of modification: reduced hours were applied most often. A Dutch study of employees with rheumatoid arthritis also found that the majority of work modifications focus on decreasing the pressure on the employee [20]. This finding may be related to the Dutch legislation, which encouraged, and still does, gradual adaptation of working hours as a general measure for supporting successful return to work. Also, it may be much easier for the employer to apply modifications to the current position than to transfer the employee to another position. Moreover, the fairly high rate of job modifications may also be explained by positive selection bias both in the recruitment of occupational physicians and employees. However, the sickness absence duration was not low in the present sample [17], suggesting that this sample was not that biased towards effective sickness absence guidance. Generally, work modifications seem more effective when sufficient consideration is given to developing a specific intervention [7, 28, 29]. In an intervention study, Steenstra et al. [29] found that workplace interventions developed by a special committee formed for each specific case appeared to be more effective for faster return-to-work than the more commonly followed procedure or through clinical intervention. Communication between the stakeholders about the work modifications appeared to be a critical factor for employer satisfaction with vocational rehabilitation [30].

We also found indications that those who returned at the end of their year of sickness absence, all had reduced hours, a new job at another department and adaptations to their work station. This may reflect their more severe or chronic condition. Moreover, we found indications that work modification which require more preparation and have a larger impact, are applied more often later during the process. Future research should show whether employees suffer from unnecessary delay when waiting for arrangements to be made.

Work modifications were applied alike in cases of mental and musculoskeletal disorders. Some indications for gender differences were found. Men with mental disorders received more often the work modification of reduced hours than men with musculoskeletal disorders while this was not found for women. Working at different schedules was more often applied for women with musculoskeletal disorders than with mental disorders and this difference was not found for men. The explanations may be gendered: working less hours may not fit with the image of working men and only applied when really urgent and changing the schedule to reduced physical overload may be related to the physical duties many women have at home.

Among both men and women who returned for the full amount of hours-which is the majority of employees who returned with higher numbers among the men-, returning to work led to some improvements of their work characteristics, but they reported higher emotional demands after returning to work as well. The latter may have to do with the demands of the return-to-work process. The women who returned for the full amount of hours were less satisfied with their pre-absence work experience than the men and this may have been related to their sickness absence. It is not clear how the improvement in work satisfaction can be explained; we have not captured this cause for this finding using the current investigation variables. It is also not clear to what extent response shifts account for the differences between pre- and post-measurement: employees may perceive their job characteristics differently due to improvements in of their illness instead of actual changes in job characteristics.

The lack of gender differences in the application of work modifications and in the change in job characteristics upon return to work in this sample may be explained by the fact that the women and men in this study had such similar characteristics. This suggests that when it comes to returnto-work measures, employers treat the job differently, rather than differentiate between women and men. In the population one finds horizontal (women and men are concentrated in different occupations), and vertical (women work in lower positions than men) gender segregation [9], which may lead to gender differences in the application of work modification and in the changing of the job characteristics upon returning to work at population level.

Strengths and Limitations

A strength of the study is the unique material collected prospectively at seven occations during the first year of sickness absence, that the employee perspective could be included, and the low drop out rate. This made it possible to study the return-to-work process in great detail. Another advantage of the research method was the comparability of the male and female employees and the large variety within 
these groups regarding demographic and employment characteristics. This allowed us to draw conclusions about gender differences without controlling for demographic and employment characteristics. Accounting for other variables was, however, not possible because of the small sample size. Moreover, due to the small sample sizes at the different measurement occasions, the statistical tests have suffered from reduced power and we may have underestimated the actual gender differences.

We may not have determined all the work modifications that were applied to the employees that were studied. The category 'other' was indicated in about a quarter of the cases rather than a specific type. Additionally, the Dutch rheumatoid patients mentioned the help received from colleagues. This was mentioned in $49 \%$ of the cases, which may indicate that this is a significant work modification for successful return to work. Furthermore, they mentioned receiving vocational training as a desired adaptation of their working environment [20]. Future studies should focus on applying work modifications in different settings (e.g., countries, sectors), include a greater variety of work modifications, and focus on the relationship between work modifications and return-to-work.

Acknowledgments The study was funded by the Dutch Ministry of Social Affairs and Employment; financial support for the writing of the article was provided by a grant from the Swedish Council for Working Life and Social Research (FAS).

Open Access This article is distributed under the terms of the Creative Commons Attribution Noncommercial License which permits any noncommercial use, distribution, and reproduction in any medium, provided the original author(s) and source are credited.

\section{References}

1. Grahn B, Ekdahl C, Borgquist L. Motivation as a predictor of changes in quality of life and working ability in multidisciplinary rehabilitation. Disabil Rehabil. 2000;22:639-54. doi:10.1080/ 096382800445443.

2. Alexanderson K, Norlund A, (eds). Sickness absence-causes, consequences, and physicians' sickness certification practice. A systematic literature review by the Swedish council on technology assessment in health care. Scand J Public Health. 2004;32 Suppl 63:1-263. doi:10.1080/14034940410024194.

3. Garcia LJ, Laroche C, Barette J. Work integration issues go beyond the nature of the communication disorder. J Commun Dis. 2002;35:187-2002.

4. Franche R-L, Cullen K, Clarke J, Irvin E, Sinclair S, Frank J, et al. Workplace-based RTW intervention literature review research team. J Occup Rehabil. 2005;15(4):607-31. doi:10.1007/s10926-005-8038-8.

5. Krause N, Frank JW, Dasinger LK, Sullivan T, Sinclair SJ. Determinants of duration of disability and return to work after work-related injury and illness: challenges for future research. Am J Ind Med. 2001;40:464-84. doi:10.1002/ajim.1116.

6. Shaw W, Feuerstein M. Generating workplace accommodations: lessons learned from the integrated case management study.
J Occup Rehabil. 2004;14(3):207-16. doi:10.1023/B:JOOR. 0000022762.66807.2d.

7. Cuelenaere B. Going on after long term sickness absence. A study on trajectories of men and women. Rotterdam: Erasmus University Rotterdam; 1997. (In Dutch: Verder na langdurig ziekteverzuim. Een onderzoek naar trajecten van mannen en vrouwen).

8. van Vuuren T, van Gent M. Re-integration of employees on longterm sickness absence: equal chances for everybody? Tijdschrift voor Arbeidsvraagstukken. 2002;18:40-53. (In Dutch: Reïntegratie van langdurig zieken: gelijke kansen voor iedereen?).

9. Holmgren K, Dahoin Ivanoff S. Women on sickness absenceviews of possibilities and obstacles for returning to work. A focus group study. Disabil Rehabil. 2004;26:213-22. doi:10.1080/0963 8280310001644898.

10. Verdonk P, de Rijk A, Klinge I, de Vries A. Sickness absence as interactive process: gendered experiences of young higher educated women with mental health problems. Patient Educ Couns. 2008;73:300-6. doi:10.1016/j.pec.2008.06.003.

11. Marmot M, Feeney A, Shipley M, North F, Syme SL. Sickness absence as a measure of health status and functioning: from the Whitehall II study. J Epidemiol Community Health. 1995;49: 24-30. doi:10.1136/jech.49.2.124.

12. Van der Giezen AM. Women, (work) conditions and disablement. Do (working) conditions cause the high increase of women into disability pension?. Amsterdam: Lisv; 2000. (In Dutch: Vrouwen, (werk)omstandigheden en arbeidsongeschiktheid. Veroorzaken (werk)omstandigheden het hoge WAO-risico van vrouwen?).

13. Sandanger I, Nygård JF, Brage S, Tellness G. Relation between health problems and sickness absence: gender and age differences. A comparison of low-back pain, psychiatric disorders, and injuries. Scand J Public Health. 2000;28:244-52.

14. Gjesdal S, Bratberg E. Diagnosis and duration of sickness absence as predictors for disability pension: results from a threeyear, multi-register based and prospective study. Scand J Public Health. 2003;31:246-54. doi:10.1080/14034940210165154.

15. Alexanderson K, Borg K, Hensing G. Sickness absence with lowback, shoulder, or neck diagnoses-an 11-year follow-up regarding gender differences in sickness absence and disability pension. Work (Reading, Mass.). 2005;25:115-24.

16. Bültmann U, Huibers M, van Amelsvoort L, Kant I, Kasl SV, Swaen GM. Psychological distress, fatigue and long-term sickness absence: prospective results form the Maastricht cohort study. J Occup Environ Med. 2005;47:941-7. doi:10.1097/01.jom. 0000172865.07397.9a.

17. De Rijk A, Janssen N, Alexanderson K, Nijhuis F. Gender differences in return to work patterns among sickness absentees and associations with health: a Dutch prospective cohort study. Int $\mathbf{J}$ Rehabil Res. 2008;31:327-36. doi:10.1097/MRR.0b013e3282 fba37c. (Internationale Zeitschrift fur Rehabilitationsforschung. Revue Internationale de Recherches de Readaptation).

18. Aarts L, de Jong $\mathrm{P}$, van der Veen R. With the best intentions. Disability pensions 1975-1999: trends, research and policy. Doetinchem: Elsevier bedrijfsinformatie; 2002. (In Dutch: Met de beste bedoelingen. WAO 1975-1999: trends, onderzoek en beleid).

19. De Vos EL, Nijboer ID, van den Heuvel SG, Hazelnet AM, Smit AA. Work modifications on return to work after sickness absence. Den Haag: VUGA; 1996. (In Dutch: werkaanpassing bij reïntegratie na ziekte).

20. Verstappen SMM, Boonen A, Bijlsma JWJ, Buskens E, Verkleij H, Schenk Y, et al. Working status among Dutch patients with rheumatoid arthritis: work disability and working conditions. Rheumatology. 2005;44:202-6. doi:10.1093/rheumatology/keh400.

21. Johansson G, Lundberg O, Lundberg I. Return to work and adjustment latitude among employees on long-term sickness 
absence. J Occup Rehabil. 2006;16:181-91. doi:10.1007/s10926006-9020-9.

22. CBS. Available from http://statline.cbs.nl (2000).

23. de Jonge J. Job autonomy, well-being, and health. PhD-thesis Maastricht University, Maastricht University, 1996.

24. Gründemann RWM, Smulders PGW, de Winter CR. Questionnaire work and health. Manual. Lisse: Swets \& Zeitlinger; 1993. (In Dutch: VAG. Vragenlijst Arbeid en Gezondheid. Handleiding).

25. van Veldhoven M, Meijman T. The measurement of psychosocial job demands with a questionnaire (VBBA). Amsterdam: Nederlands Instituut voor Arbeidsomstandigheden; 1994. (In Dutch: Het meten van psychosociale arbeidsbelasting met een vragenlijst: de vragenlijst Beleving en Beoordeling van de Arbeid (VBBA))

26. CBS. Life situation of the Dutch population 1997-part 1: health and quality of work. Voorburg/Heerlen: CBS; 1999. (In Dutch: De leefsituatie van de Nederlandse bevolking 1997-deel I: Gezondheid en kwaliteit van de arbeid).
27. Karasek RA. Job content questionnaire and user's guide. Lowell: Department of Work Environment, University of MassachussetsLowell; 1985.

28. Houtman I. Reliability and validity of the Dutch version of the Karasek job content questionnaire. Paper presented at the NIOSH/APA conference on Stress, Work and Health. Washington, DC, 1995.

29. Steenstra IA, Koopman FS, Knol DL, Kat E, Bongers PM, de Vet HC. Prognostic factors for duration of sick leave due to low-back pain in Dutch health care professionals. J Occup Rehabil. 2005;15:591-605. doi:10.1007/s10926-005-8037-9.

30. Kyes KB, Wickizer TM, Franklin G. Employer satisfaction with workers' compensation health care: results of the Washington state workers compensation managed care pilot. J Occup Environ Med. 2003;45:234-40. doi:10.1097/01.jom.0000058337.05741.a1. 